\title{
In Vitro Antioxidant, Membrane Stabilizing and Antimicrobial Properties of Murayya paniculata Wild Plant of Amarkantak (M.P)
}

\author{
Shruti Sonter \\ Indira Gandhi National Tribal University \\ Shringika Mishra \\ Indira Gandhi National Tribal University \\ Manish Dwivedi \\ Indira Gandhi National Tribal University \\ Prashant Singh ( $\sim$ prashant.singh@igntu.ac.in ) \\ Indira Gandhi National Tribal University
}

\section{Research Article}

Keywords: Traditional medicine, Antimicrobial, antioxidant, membrane stabilizing, Murayya paniculata, GC-MS

Posted Date: January 4th, 2021

DOI: https://doi.org/10.21203/rs.3.rs-135362/v1

License: () (1) This work is licensed under a Creative Commons Attribution 4.0 International License. Read Full License 


\section{Abstract}

The excessive usage of antibiotics in humans and veterinary medicine has lead to the emergence of antibiotic resistance and requirement of novel antibiotics. There has been increased interest towards plants as source of drugs because of their pharmacological potency and long traditional usage. The aim of the current study was to evaluate bioactive components, antioxidant and anti-inflammatory activity from the leaf extracts of Murayya paniculata, a traditionally used Indian medicinal plant. Evaluations were made for phytochemicals, antioxidant, membrane stabilizing and antimicrobial activities. The methanol extract displayed highest flavonoid and phenolic content while the acetone extract demonstrated considerable ABTS inhibitory activity (IC ${ }_{50}$ value:555.18 \pm $1.68 \mu \mathrm{g} / \mathrm{mL}$ ) and hexane extract exhibited highest $\mathrm{H}_{2} \mathrm{O}_{2}$ radical scavenging activity $\left(\mathrm{IC}_{50}\right.$ value: $\left.509.84 \pm 3.03 \mu \mathrm{g} / \mathrm{mL}\right)$. The aqueous extract displayed $19.4 \pm$ $0.66 \%$ RBC hemolysis and $80.5 \pm 0.66 \%$ protection caused by hypotonic solution at high concentration of extract. The fractions of hexane extract revealed a higher zone of inhibition than crude extract. The major components found in the fractions were cyclohexane (40.11\%) and 3-(6-Methoxy-3-methyl-2benzofuranyl) Cyclohexanone (13.68\%) analyzed by GC-MS technique. The current results validate the traditional use of the plant and warrant its potential in drug development programs in further investigations.

\section{Introduction}

The discovery of compounds with antimicrobial properties has revolutionized modern medicine system. Use of antibiotics has provided us with successful interventions in surgical procedures, organ transplants and patient care. However, the evident reports of antimicrobial resistance amongst common bacterial pathogens are now threatening this therapeutic accomplishment [1]. A large number of diseases such as pneumonia, tuberculosis, gonorrhoea, and salmonellosis are becoming harder to treat with the currently available antibiotics. It has been estimated that around 300 million premature deaths will occur by 2050 with a global economic loss of up to $\$ 100$ trillion [2]. The resistance against antibiotics is an immediate threat to the treatment of infectious diseases as the development of new antimicrobial agents is declining and very few drugs have been approved in the recent years [3]. Phytochemicals have displayed potential antibacterial properties against sensitive and resistant pathogens and thus priority research for screening plant extracts for novel antimicrobial properties can be a possible source for a new drug development[4][5]. Plants possess variety of secondary metabolites that can be utilized for the development of biocompatible therapeutics. Traditional medicinal systems, being practiced in major parts of the world are based on therapeutic use of such medicinal plants. WHO have also emphasized that several countries are gradually accepting the contribution of traditional medicine to the health and wellbeing of individuals and the need to integrate it to their healthcare systems [6]. Thus, it is quite rational that plants be selected based on traditional medicinal knowledge and screened for characterization of natural products as novel antimicrobials.

Murayya paniculata (Synonyms: Cholcas paniculata L, Chalcas exotica L and Murayya exotica L.,) commonly known as Orange Jasmine, mock orange, chinese box, Kamini, is a tropical, evergreen plant with tiny, white, scented flowers, and is cultivated as an ornamental tree or hedge [7]. The leaves have been used as a food additive in many Indian and Malay dishes due to their strong fragrance. The plant is known for its therapeutic usage and has been traditionally used for the treatment of tuberculosis, diarrhea, abdominal pain, dysentery, headache, edema, thrombosis, and stasis of blood. Traditional medicinal healers of Amarkantak region utilize medicinal plants for the treatment of various diseases. In our initial studies we found $M$. paniculata to be one such promising plant used by the healers for the successful treatment of wounds, tuberculosis, malaria and as an antidote. The different parts of the plant such as leaves, roots, and stem are used in the preparation. As to the best of our knowledge, there is no reference about the safe prescribed amount of $M$. paniculata in traditional medicine so it was considered worthwhile to do the pharmacological activities such as antioxidant, antimicrobial, anti-inflammatory etc. The present study was undertaken to compare efficiency of different leaf extracts to find out the phyto-constituents, total phenolic, total flavonoid content, total reducing power and antimicrobial property against selected microbial strains. As per our knowledge this is the first reporting of the comparative account of the pharmacological efficiency of different leaf extracts of M. paniculata.

\section{Results}

\subsection{Extract Preparation}

The extracts were prepared using dried leaves of the plant in different solvents such as hexane, acetone, chloroform, methanol and water. The results display that maximum yield per gram is obtained from methanol $(4.8 \% \mathrm{w} / \mathrm{w})$ followed by acetone $(3.7 \% \mathrm{w} / \mathrm{w})$, water $(3.47 \% \mathrm{w} / \mathrm{w})$, hexane $(1.78 \% \mathrm{w} / \mathrm{w})$ and chloroform $(1.07 \% \mathrm{w} / \mathrm{w})$. This highlights that methanol is efficient solvent for extraction of phytochemicals from leaves of $M$. paniculata.

\subsection{Phytoconstituents analysis}

Alkaloids, flavonoids, steroids and terpenoids were detected as major secondary metabolites in the plant extracts. Tannins, saponins and glycosides were present in minor quantities while phlobatanins and terpenoids were not present in any of the extracts (Table S1).

\subsection{Antioxidant activity}

The total phenolic and total flavonoid content in the different extracts of $M$. paniculata is represented in Table 1. Among the five extracts methanol extract possesses highest phenolic content $(14.45 \pm 0.63 \mathrm{mg}$ gallic acid equivalent $/ \mathrm{g}$ dry material) followed by acetone $(12.02 \pm 0.59 \mathrm{mg} / \mathrm{g}), \mathrm{water}(3.20 \pm 0.12 \mathrm{mg} / \mathrm{g})$ chloroform $(1.68 \pm 0.06 \mathrm{mg} / \mathrm{g})$ and hexane $(1.01 \pm 0.01 \mathrm{mg} / \mathrm{g})$. The total flavonoid concentration in different solvent extracts was estimated using quercetin as a standard and values expressed in $\mathrm{mg}$ quercetin equivalent $/ \mathrm{g}$ dry wt. Out of five extracts the methanol ( $1.987 \pm 0.04 \mathrm{mg})$ contains highest flavonoid content followed by water $(1.619 \pm 0.04 \mathrm{mg})$, acetone $(1.004 \pm 0.02 \mathrm{mg})$, hexane $(0.614 \pm 0.08 \mathrm{mg})$ and chloroform $(0.609 \pm 0.03 \mathrm{mg})$. Supplementary figure (Fig. S1) shows the different concentration of plant extract with percentage inhibition of ABTS radical, out of which the acetone extract demonstrated elevated ABTS ${ }^{+}$ inhibition with increased concentration. For $\mathrm{ABTS}^{+}$inhibition the $\mathrm{IC}_{50}$ values ranged between $500-800 \mu \mathrm{g} / \mathrm{mL}$ (Table 2$)$. The IC ${ }_{50}$ value of acetone $(555.18 \pm$ 
$1.68 \mu \mathrm{g} / \mathrm{mL}$ ) were less than the standard (Ascorbic acid) used. The percentage $\mathrm{H}_{2} \mathrm{O}_{2}$ inhibition by different extracts was found to be concentration dependent (Fig. S2). The hexane extracts exhibited highest $\mathrm{H}_{2} \mathrm{O}_{2}$ scavenging ability compared to other extracts. The IC ${ }_{50}$ values ranged between $500-800 \mu \mathrm{g} / \mathrm{mL}$ Table 2 . The $\mathrm{IC}_{50}$ value of hexane $(509.84 \pm 3.03 \mu \mathrm{g} / \mathrm{mL}$ ) was lowest as compared to the standard (Ascorbic acid) or other extracts that were analyzed. The result display that hexane and acetone have better antioxidant property as compared to the standard.

The analysis of total reducing capacity of extracts was carried out using FRAP and reducing power assays. FRAP value of methanolic extract ( $0.085 \pm$ $0.002 \mu \mathrm{g} / \mathrm{mL}$ ) showed highest value, followed by acetone, water, chloroform and hexane (Table 2) The reducing property of compound/ extracts indicates its electron donating capacity. In reducing power assay, the M. paniculata methanol extract displayed maximum absorbance followed by water, acetone, ascorbic acid, hexane and chloroform extracts (Fig. 1).

\subsection{Membrane stabilizing property}

The results of assay are presented in Table 3. It was observed that all the extracts of $M$. paniculata exhibited concentration dependent anti-inflammatory property as compared to the standard drug indomethacin. The maximum concentration analyzed was $5000 \mu \mathrm{g} / \mathrm{mL}$ and extracts were found to possess antiinflammatory property in the order MPW $>$ MPM $>$ MPH $>$ MPA $>$ MPC. The aqueous extract showed the $80 \%$ protection whereas the standard drug showed $83 \%$ protection at highest concentration tested. The Pearson's correlation was done with concentration against percent protection provided by different extracts (Table S2), where we found strong positive correlation with concentration and percent protection with all extracts.

\subsection{Antimicrobial activity}

Table 6 presents antimicrobial activity against tested bacterial (E. coli, S. aureus, P. auregenosa, B. subtilius) and fungal (C. albicans, P. chrysogenum, A. niger, A. flavus) strains using disk diffusion method (Fig. 2). The growth of $P$. auregenosa was inhibited by all extracts of $M$. paniculata. The MIC for different extracts was as aqueous $(25 \mu \mathrm{g} / \mathrm{mL})$, hexane, methanol, and chloroform $(250 \mu \mathrm{g} / \mathrm{mL})$, acetone $(500 \mu \mathrm{g} / \mathrm{mL})$. The hexane extract displayed good inhibition activity against all the bacterial strains as compared to other tested extracts. All the extracts were found not be active against any fungi as we did not observed any zone of inhibition even after repeated experiments.

\subsection{Fractionization of Hexane Extract}

Total 13 fractions were collected initially using column chromatography. The results of TLC showed that F1- F3 contain single spot and were eluted using hexane and dichloromethane (5:5) as the solvent. The fractions were pooled and renamed as PC1. The F9 \& 10 showed similar spot and were pooled as PC3. Further F11-13 had similar spots and was renamed as PC4. The F4 to F8 displayed 3 spots on TLC ( 2 spots in UV and 1 spot in Vis) which were concentrated and further allowed for column chromatography separation using mixture of hexane and acetone as solvent. From the repeated chromatography we obtained fraction PC2 (in visible region), PC11 and PC22 (in UV region). Finally 6 pooled fractions were obtained, named as PC1, PC2, PC3, PC4, PC11, PC22 and used for further antibacterial activities.

\subsection{Antibacterial activity}

Table 4 presents antimicrobial activity against selected multi resistance bacteria ( $E$. coli, S. aureus, P. auregenosa, $B$. subtilius) using fractions obtained from column chromatography. The $B$. subtilius and $P$. auregenosa were inhibited by all fractions of hexane extract, out of which PC4 showed MIC of 250 and $25 \mu \mathrm{g} / \mathrm{mL}$ respectively (Fig 3$)$.

\subsection{GC-MSMS of PC4 fraction of Hexane extract:}

The fraction (PC4) exhibiting significant antibacterial activity was subjected to analysis by GC/MSMS technique. The major antibacterial components found in the fractions were Cyclohexane (40.11\%) and 3-(6-Methoxy-3-methyl-2-benzofuranyl) Cyclohexanone (13.68\%) as shown in Table 5 and Fig.4 . The supplementary figure (Fig S3) shows MS spectrum of major components identified through GC-MSMS analysis.

\section{Discussion}

Amarkantak is located in an ecologically diverse region in the states of Chhattisgarh and Madhya Pradesh (India). Several tribal and non-tribal communities reside in this area and utilize the forest produce for their livelihood and other needs. Being biodiversity rich, Amarkantak is a potential source of hundreds of medicinal plants that are being utilized by the tribal communities for the treatment of various health problems. M. paniculata is used by them for treatment of tuberculosis, malaria, wound healing and as an antidote. We therefore selected M. paniculata leaves for investigation of antioxidant, membrane stabilizing and antimicrobial properties. The phytochemical screening divulges the presence of alkaloids, flavonoids, steroids, tannins, saponins and glycosides that are known to have protective or disease preventive properties. Several phytochemicals plays vital role in alleviating the several health problems like malaria, asthma, cancer, arthritis, jaundice, diabetes, dengue, diarrhea, dysentery and microbial infections [8]. In the current study, secondary metabolites such alkaloids, flavonoids, steroids and terpenoids present in majority while tannins, saponins and glycosides were present in minor quantities. The alkaloids are a class of nitrogenous compounds that have served as scaffolds for important antibacterial drugs such as metronidazole and the quinolones [9][10]. More than 8000 flavonoids have been reported from different plants species [11]. That play vital role in stimulation, protection, flavoring, communication, and pigmentation [12]. Flavonoids are rich source of antioxidants and are known to protect plants against various stresses [13]. The flavonoids are known to possess anti-allergic, hepatprotective anticancer, antibacterial, anti-inflammatory, anti-diabetic and anti-viral properties [14][15][16][17][18]. Saponins are a vast group of compounds distributed widely in the plant kingdom, which are characterized by their foam forming and detergent properties [19][20][21]. They are known to have several biological properties like antimicrobial, anti-malarial, anti-allergic, anti-diabetic, insecticidal, and anti-inflammatory [22][23][24][25][26]. The tannins (commonly referred to as tannic acid) are water soluble polyphenolic compounds synthesized by plants [22] and are responsible to protect plants 
against herbivores and insects [27][28]. Tannins have also been reported to have anti cancer, anti mutagenic, anti-oxidant, antibacterial, anti-viral, anti-tumor, and anti-inflammatory activities [28][29][30][31][32][33]. The presence of all these compounds in the leaves highlights the prominent use of $M$. paniculuta for the treatment of various diseases by the tribal communities. The total phenolic content was present in high concentrations in methanolic extract followed by acetone, water, chloroform and hexane while the total flavonoid content was highest in methanol extract followed by water, acetone, hexane and chloroform. The antioxidant activity of flavonoids is due to their ability to reduce free radical formation and to scavenge free radicals. Previously Zhang et al. (2011) reported the presence of seventy polymethoxylated flavonoids (PMF) in the leaves extract of M. paniculata [34]. These PMFs are a particular group of flavonoids that are responsible for a number of biological activities including antioxidant [35][36]. and antimicrobial activities [37][38]. Phenolic compounds are good antioxidants as their hydroxyl groups can directly contribute to antioxidant action leading to a wide range of biological effects including antibacterial, anti-inflammatory, antiallergic, hepato-protective, antithrombotic, antiviral, anticarcinogenic and vasodilatory actions [39]. Some phenolic compounds can stimulate the synthesis of endogenous antioxidant molecules in the cell [40]. The results of antioxidant activities correlated well with the presence of phenolic and flavonoids in different extracts. Significant concentration dependent inhibition of ABTS free radical was observed in all the tested extracts. The $\mathrm{IC}_{50}$ value observed for acetone extract was even less than the standard ascorbic acid that indicates the strong ability of the extracts to act as ABTS and $\mathrm{H}_{2} \mathrm{O}_{2}$ scavenger. Significant dose-dependent $\mathrm{H}_{2} \mathrm{O}_{2}$ scavenging activities were observed in all the extracts analyzed. The lowest IC 50 (509.84 $\left.\mu \mathrm{g} / \mathrm{mL}\right)$ was observed for the hexane extract that was lower than that of ascorbic acid (528.01 $\mu \mathrm{g} / \mathrm{mL})$ although it was observed that at low concentrations ascorbic acid was found to be more efficient. The reducing capacity of antioxidant is mainly because of their electron transfer property for instance polyphenols and flavonoids [41]. The FRAP assay is a relatively simple, quick, and inexpensive direct method of measuring the combined antioxidant activity of reductive antioxidants in a test sample [42]. The higher values shows, higher antioxidant property of extracts. Our study clearly indicated that the methanolic extract of the leaves exhibited high scavenging capacity demonstrating that the high antioxidant capacity of the methanol extract that correlated well with the total content of phenolic and flavonoid content. Higher the absorbance shows higher antioxidant property. The present study also demonstrated the results that total antioxidant reducing power of compound/extract is depending on the amount of phenolic and flavonoid content. The comparison between the results of total phenolic content and reducing power assay found to be in similar order of MPM $>$ MPW $>$ MPA $>$ MPH $>$ MPC. Whereas the results of total flavonoid content and FRAP values found to be in similar order of MPM $>$ MPA $>$ MPW $>$ MPC $>M P H$. Many studies demonstrated the strong correlation between the phenolic content and reducing property of compounds. The redox properties of phenolic are major reason for the antioxidant property of an extract [43] [44].

Living tissues respond to injury, infection or irritation in the form of inflammation. Lysosomal enzymes are released leading to the tissue injury by damaging the macromolecules and lipid peroxidation of membranes. Plant extracts can be utilized for stabilization of lysosomal membrane and thus limiting the inflammatory response by inhibiting the release of lysosomal constituents of activated neutrophil such as bactericidal enzymes and proteases. Human red blood cell or erythrocyte membrane is analogous to the lysosomal membrane and has been used in stabilization assays. The antioxidant activity of the $M$. paniculata extracts correlated well with the RBC membrane stabilization properties. At the concentrations of $4000-5000 \mu \mathrm{g} / \mathrm{mL}$, we observed $60-80 \%$ protection that was comparable to the standard drug indomethacin in RBC hemolysis with water and methanol extract. The results clearly suggest that M. paniculata extracts may provide us with some potent compounds for the management of inflammatory conditions. Presence of saponins and flavonoids in the methanolic and water extracts also support the current findings as they have been known to have profound stabilizing effect on lysosomal membrane [45].

Novel safe and promising antimicrobial agents are urgently required to fight against drug resistant bacterial and fungal strains. Flavonoids are known to inhibit microbial growth by inhibition of nucleic acid synthesis, cytoplasmic membrane function and energy metabolism pathways [46]. The antimicrobial properties of phenolic compounds have been reported due to the alteration of cell membrane permeability leading to the uncoupling of oxidative phosphorylation, inhibition of active transport and cytoplasmic membrane damage that leads to the loss of pool metabolites [47]. Tannins have been shown to possess inhibitory activities against Methicillin-resistant Staphylococcus aureus (MRSA) [48] or bacteria, yeast and fungi [49]. In the current study all the extracts of M. paniculata displayed some level of inhibition of bacterial growth but no antifungal activity was observed. Both the Gram negative and Gram positive bacteria were inhibited by the extracts, however the hexane extract exhibited growth inhibition against all tested bacterial strains with a minimum observed MIC of $50 \mu \mathrm{g} / \mathrm{mL}$ against $B$. subtilis or MIC $250 \mu \mathrm{g} / \mathrm{mL}$ against $P$. aerugonesa. Fractionisation of hexane extract yielded six fractions that revealed promising antibacterial potency. This showed that $M$. paniculata extracts contains potential antibacterial bioactive components but not good antifungal agents. The $P$. aeruginosa was found to be very sensitive to the fractions of hexane extract displaying an inhibition zone of $9.6 \mathrm{~mm}$ against $\mathrm{PC} 2$ fraction. Whereas the PC4 fraction exhibited considerable antibacterial activity against all tested strains. Hence result predicts that PC4 fraction would be an active and efficient compound/s against selected bacterial strains.

The GC-MSMS analysis of PC4 fraction revealed a presence of cyclohexane and 3-(6-Methoxy-3-methyl-2- benzofuranyl) Cyclohexanone in highest amount proved to be a reason for antibacterial activity. The cyclohexane and derivates are lipophilic weak acids and possess exceptional nature of mode of action as antibacterial agents. Unlike other cationic antimicrobial compounds, these cyclohexane and derivatives will not interrupt the cytoplasmic membrane instead they block the transport of low molecular weight hydrophobic substances of bacterial cell [50]. Among the heterocyclic ring compounds, such as benzofuran is a significant class of compounds obtained its vital place in numerous pharmacological areas and it could be a one such reasons for the active biological properties of natural products [51]. The derivatives of benzofuran exhibited many noteworthy activities against viruses, fungi[52][53], protozoan, tuberculosis [54] and so on. Therefore, the wide range of biological importance coupled with this scaffold has resulted in the cyclohexane and benzofuran ring system being considered as a privileged structure. There is a strong attention is required on cyclohexane derivatives and benzofuran-based medicinal agents and the extended research and development to increase active domains of research to the whole range of medicinal areas. A great effort have been invested in the past decades to develop more effective and less toxic agents to treat many infectious and resistant strains of microbes. These cyclohexane and benzofuran based compounds as microbial agents could be a promising, as they possess the structural diversity and excellent therapeutic potency. Our antibacterial activity results supported the previous studies and further highlighted the importance of using plants as therapeutic agents.

\section{Conclusion}


The current study illustrates that the M. paniculata leaves extracts possess potent antioxidant activity. It was also observed that the M. paniculata leaf extracts could stabilize the human RBC membrane in a dose dependent manner and thus provides us with anti-inflammatory molecules. The preliminary chemical examination of different extracts reveal the presence of flavonoids, alkaloids, tannins and polyphenols that might be responsible for the antioxidant and RBC membrane stabilization activities. The PC4 is the most potent hexane fraction that was bactericidal against $E$. coli, $B$. subtilius, $P$. aeruginosa, $S$. aureus and further characterization revealed the cyclohexane and banzofuran derivatives as novel antimicrobial agents. The overall results of the present study can be considered as very promising in the prospective of new anti microbial drug discovery from traditionally used plant, especially against multi drug resistant bacterial strains.

\section{Materials And Method}

5.1 Preparation of extracts:M. paniculata leaves were collected from the Amarkantak region, District Anuppur, Madhya Pradesh (India). The leaves were washed under tap water, shade dried and finally grinded it into fine powder form. The extraction was carried out using different solvents (hexane, acetone, chloroform, methanol and water) for about 7-8 hours using Soxhlet extractor and concentrated using rotary evaporator. The extract was dried and stored in vials at $4^{0} \mathrm{C}$ till future use.

\subsection{Phytochemical screening}

The phytochemical screening of all extracts was carried out according to standard methods as mentioned elsewhere with minor modifications [55][56][57].

\subsection{Total phenolic content}

The total phenolic content was determined for different $M$. paniculata extracts using spectrophotometric method [58]. Different extracts were taken at concentration $1 \mathrm{mg} / \mathrm{mL}$ for analysis. The reaction mixture was prepared (in triplicate) by mixing $0.5 \mathrm{~mL}$ of individual extracts, $2.5 \mathrm{~mL}$ of $10 \%$ Folin-Ciocalteu's reagent dissolved in water and $2.5 \mathrm{~mL} 7.5 \% \mathrm{NaHCO}_{3}$. The samples were incubated for $45 \mathrm{mins}$ at $45^{\circ} \mathrm{C}$ and the absorbance was measured at $765 \mathrm{~nm}$ using spectrophotometer (Shimadzu UV-Vis spectrophotometer-1800). Based on the measured absorbance, the total phenolic content in the test samples was calculated using the calibration plot $(Y=0.00023 x+0.0380, R 2=0.998)$ and expressed in terms of Gallic acid equivalent (mg of GA/g of extract).

\subsection{Total flavonoids content:}

The total flavonoid content was performed as per Dowd method with some modifications for the different extracts [59][60][61]. Different extracts were taken at $1 \mathrm{mg} / \mathrm{mL}$ concentration for analysis and reaction mixture prepared by mixing $0.5 \mathrm{~mL}$ of extracts, $10 \%$ aluminium chloride $(0.1 \mathrm{~mL}), 1 \mathrm{M} \mathrm{potassium}$ acetate $(0.1 \mathrm{~mL})$ and distilled water $(4.3 \mathrm{~mL})$. Reaction mixture was incubated at room temperature for 30 mins and absorbance was measured at $510 \mathrm{~nm}$.Quercetin $(1 \mathrm{mg} / \mathrm{mL})$ was used for preparing the standard calibration curve. The total flavonoid content in the test samples was calculated using the calibration plot $(Y=$ $\left.0.004 x+0.158, R^{2}=0.997\right)$ and expressed as mg quercetin equivalent (QE)/g of dried plant material.

\subsection{Anti oxidant assays}

5.5.1 ABTS (2,2'-azino-bis(3-ethylbenzothiazoline-6-sulfonic acid) assay: ABTS is a synthetic radical widely used for both the polar and non-polar samples [62]. Mixture of ABTS $(14 \mathrm{mM})$ and potassium per sulfate $(4.95 \mathrm{mM})(1: 1 \mathrm{v} / \mathrm{v})$ was prepared and allowed to stand overnight at room temperature (RT) in dark. $\mathrm{ABTS}^{+}$was diluted with water to obtain equilibration of absorbance $0.70( \pm 0.02)$ at $734 \mathrm{~nm}$ and suitable blank was used without test adding samples. $50 \mathrm{mg} / \mathrm{mL}$ stock solutions of plant extracts were prepared and different concentrations used for assay. The following formula was used to calculate percentage of inhibition.

\section{Percentage of ABTS inhibition $=(A 0-A 1 / A 0) X 100$ $\mathrm{A}_{0}$---- Absorbance of blank $\mathrm{A}_{1}$---- Absorbance of Sample}

5.5.2 Hydrogen peroxide ( $\mathrm{H} 2 \mathrm{O} 2)$ radical scavenging assay: Hydrogen peroxide radical scavenging activity was determined according to the method of Ruch et al (1989) [63]. $40 \mathrm{mM} \mathrm{H}_{2} \mathrm{O}_{2}$ solution was prepared in 50mM phosphate buffer ( $\mathrm{pH} 7.4$ ). 3.4mL of different concentrations of extracts (1000, 2000, 3000, 4000, and $5000 \mu \mathrm{g} / \mathrm{mL}$ ) were added to $0.6 \mathrm{~mL}$ of $\mathrm{H}_{2} \mathrm{O}_{2}$ solution. The absorbance was read at $230 \mathrm{~nm}$ after 10 minutes of incubation at RT against a blank solution containing only phosphate buffer without $\mathrm{H}_{2} \mathrm{O}_{2}$.

\section{Percentage of scavenged $\mathrm{H} 202=(A 0-A 1 / A 0) X 100$ \\ $\mathrm{A}_{0}$---- Absorbance of blank \\ A 1 ---- Absorbance of Sample}

5.5.3 Ferric Reducing Antioxidant Power (FRAP) assay: The total antioxidant potency of extracts of M. paniculata was estimated using a ferric reducing antioxidant power (FRAP) assay [64]. FRAP reagent (straw yellow color) was prepared by mixing $30 \mathrm{mM}$ acetate buffer, $10 \mathrm{mM}$ TPTZ, $20 \mathrm{mM} \mathrm{FeCl}{ }_{3}$ and distilled water. The standard curve of ferrous sulfate $\left(\mathrm{FeSO}_{4} .7 \mathrm{H}_{2} \mathrm{O}\right)$ was prepared with concentrations ranging from $0.1,0.2,0.4,0.4,0.6,0.8$ and $1.0 \mathrm{mM} / \mathrm{L}$. Different concentrations of ascorbic acid and sample $(1000,2000,3000,4000$, and $5000 \mu \mathrm{g} / \mathrm{mL}$ ) were prepared from $1 \mathrm{mg} / \mathrm{mL}$ stock solution and $3 \mathrm{~mL}$ of FRAP reagent added to each and the tubes were incubated for 30 minutes in the dark, read absorbance at $593 \mathrm{~nm}$. 
5.5.4 Reducing power assay (RPA): The total reducing power of extracts was estimated by the method of Oyaizu et al (1986) [65]. The different concentrations of plant extracts $(1 \mathrm{~mL}$ of $1000,2000,3000,4000$, and $5000 \mu \mathrm{g} / \mathrm{mL}$ ) were mixed with $5 \mathrm{~mL}$ of $0.2 \mathrm{M}$ phosphate buffer $(\mathrm{pH}-6.6)$, and $5 \mathrm{~mL}$ of $1 \%$ ferricyanide was added and incubated for 20 minutes at $50^{\circ} \mathrm{C}$. After incubation the $10 \%$ trichloro acetic acid (TCA) added and centrifuged at $3000 \mathrm{rpm}$ for $10 \mathrm{minutes}$. To the supernatant equal amount of water and $1 \mathrm{~mL}$ of $1 \%$ ferric chloride were added, absorbance read at $700 \mathrm{~nm}$. Higher the absorbance value of the reaction mixture indicated better reducing power

\subsection{Membrane stabilizing property}

The human red blood cell (HRBC) membrane stabilization method is mainly used to estimate the anti-inflammatory activity of plant extracts [66]. The fresh blood was collected and mixed with an equal volume of sterilized Alsever's solution ( $2 \%$ dextrose, $0.8 \%$ sodium citrate, $0.5 \%$ citric acid, and $0.42 \%$ sodium chloride in water). (Administration of NSAIDS for 2 weeks before collecting the blood was avoided). The collected blood was further centrifuged at 3000 rpm for $10 \mathrm{~min}$, and the pellet (packed cells) were washed thrice with isosaline (0.85\%, pH 7.2) and finally $10 \%$ (v/v) suspension was made with isosaline. To the different concentrations of plant extracts, $1 \mathrm{~mL}$ phosphate buffer (0.15 M, pH 7.4), $2 \mathrm{~mL}$ hyposaline (0.36\%), and 0.5mL HRBC suspension was added. Standard and control were prepared without addition of the extracts. Indomethacin at different concentrations $(1000,2000,3000,4000, a n d 5000 \mu \mathrm{g} / \mathrm{mL}) \mathrm{was}$ used as the standard drug and compared with respective concentrations of plant extract. The reaction mixtures were incubated at $37^{\circ} \mathrm{C}$ for 30 min and centrifuged at $3000 \mathrm{rpm}$ for $10 \mathrm{~min}$. The hemoglobin content in the supernatant was estimated at $560 \mathrm{~nm}$ [67].

The percentage hemolysis was calculated using the following equation:

\section{Percentage of scavenged $\mathrm{H} 2 \mathrm{O} 2=(A 0-A 1 / A 0) X 100$ $\mathrm{A}_{0}$---- Absorbance of blank A ---- Absorbance of Sample}

The percentage of HRBC membrane stabilization was calculated using the following equation:

$$
\% \text { Protection }=[100-(O D \text { of test sample }- \text { OD of control })] \times 100
$$

\subsection{Antimicrobial assay}

Crude extracts were evaluated for their antimicrobial properties against selected bacterial (Escherichia coli MTCC 1575, Staphylococcus aureus MTCC 1144, Bacillus subtilis MTCC 2413, Pseudomonas aeruginosa MTCC 1688) and fungal (Candida albicans MTCC 854, Peniccillin chrysogenum MTCC 1996, Aspergillus niger MTCC 872 and A. flavus MTCC 1883) strains. Standard drugs Amphotericin and Ciprofloxacin were used as positive controls.

\subsubsection{Agar diffusion method}

The stock cultures of bacteria were revived by inoculating in broth media and grown at $37^{\circ} \mathrm{C}$ for $18 \mathrm{hrs}$. The agar plates were prepared, after solidification the $100 \mu \mathrm{l}\left(10^{-4} \mathrm{cfu}\right) 18 \mathrm{~h}$ old culture inoculated and evenly spread. After $20 \mathrm{~min}$, the wells were filled with test compounds at different concentrations ( 1000,500 , $250,100,50,25 \mu \mathrm{g} / \mathrm{mL}$ ) kept for incubation at $37^{\circ} \mathrm{C}$ for of $24 \mathrm{~h}$. The diameter of inhibition zones measured and noted as described earlier [68][69]. Minimum inhibitory concentration (MIC) was calculated using the same plate.

\subsection{Column chromatography of hexane extract}

The most active crude extract (hexane extract) was allowed to separate using gravitation column chromatography. The slurry was prepared by mixing $500 \mathrm{~g}$ of absorbent (silica gel 60-120 mesh size) in n-hexane and stirred well to remove bubbles then poured in to glass column. The sample to be loaded on column was prepared by dissolving $5 \mathrm{~g}$ of extractin $25 \mathrm{ml}$ of hexane and $20 \mathrm{~g}$ of silica. In Table S3, we review the ratio of solvents and fractions obtained in the column chromatography. Each fraction was spotted on activated TLC plate along with extract spot and mobile phase [Hexane: acetone (3:1)] used. The fractions showing more than one spots were concentrated and allowed for further purification using only different solvent mixtures (Hexane and Acetone). The column chromatography was repeated as the eluent system to obtain a single spots on TLC.

\subsection{Antibacterial activity}

The different fractions collected from the hexane extract were further evaluated for antibacterial activity as mentioned earlier and the zones of inhibition were recorded.

\subsection{GC-MSMS analysis}

The GC-MSMS analysis of PC4 fraction of M.paniculata hexane extract was carried out on Agilent technologies model 7890A GC coupled with a mass detector 5975C MS system. The Analytic column was Agilent J\&W nonpolar column DB-5MS ((5\%-Phenyl)-methylpolysiloxane, $30 \mathrm{~m} \times 0.25 \mathrm{~mm}$, ID $1.8 \mathrm{micron}$ thickness). Flow rate of helium gas is $1.3 \mathrm{ml} / \mathrm{min}$, used to separate components. The different GC conditions were standardized as follows; injector parameters were injection volume $1 \mu \mathrm{L}$ under split of $3: 1$, while injector temperature was set at $280^{\circ} \mathrm{C}$ (mass analyzer). During GC extraction the program of oven temperature was $1 \mathrm{~min}$ at $75^{\circ} \mathrm{C}$, increased to a temperature of $300{ }^{\circ} \mathrm{C}$ at a rate of $30^{\circ} \mathrm{C} / \mathrm{min}$ for 2 mins; inlet and transfer line temperature was $250{ }^{\circ} \mathrm{C}$ and $290^{\circ} \mathrm{C}$ respectively. Mass spectra were taken at an ionization mode with an electron impact at $70 \mathrm{eV}$. Interpretation of mass spectrum GCMSMS analysis was 
done by matching list of known compound's spectrum with Agilent's GC/MS Chemstation, NIST MS Library and NIST's Automated Mass Spectral Deconvolution and Identification software [70].

\section{Statistical analysis}

All datawere expressed as mean \pm SD of triplicates. Comparison of mean values between various extracts of M. paniculata were performed by one wayANOVA, correlation coefficient $(r)$ and coefficient of determination $\left(r^{2}\right)$ calculated using prism 8.0.1(244). The $p<0.001$ was considered to be statistically significant.

\section{Declarations}

\section{Acknowledgement}

The Department of Biotechnology, Indira Gandhi National Tribal University, Amarkantak, Madhya Pradesh, India, is acknowledged for providing the basic infrastructure for carrying out the research work.

\section{Authors' contributions}

SS, SM and MKD collected the plant materials, performed the experiments, analyzed the data and wrote the manuscript. PKS: Designed the study, analyzed the data, and wrote the manuscript. All authors have read and approved the final manuscript.

\section{Funding}

The funding in the form of departmental grant was provided by Indira Gandhi National Tribal University, Amarkantak, Madhya Pradesh, India. No external funding was received for the research work. The funders had no role in the study design, experimental work, or manuscript preparation.

\section{Availability of data and materials}

The data can be accessed/shared to the public.

Ethics approval and consent to participate: All procedures performed in studies involving human participants were in accordance with the ethical standards of the Institutional Ethics Committee of IGNTU (Approval no. IGNTU/IEC/03/2019) and with the 1964 Helsinki declaration and its later amendments. Self blood was used for the membrane stabilizing assay and no external participant was enrolled for the study.

\section{Consent for publication}

Not applicable

\section{Conflict ofinterests}

The authors declare no conflict of interest.

\section{References}

1. Munita, J.M. \& Arias, C.A., Mechanisms of Antibiotic Resistance. Microbio/ Spectr. 4 (2). VMBF-0016-2015, (2016).

2. O'Neill, J., Antibiotic Resistance Threats in the United States. Centers for Disease Control and Prevention. https://www.cdc.gov/drugresistance/pdf/arthreats-2013-508.pdf (2016)

3. Conly,J. \& Johnston, B. Where are all the new antibiotics? The new antibiotic paradox. Can J Infect Dis Med Microbiol.16(3), 159-160 (2005).

4. Gautam, M.K., Gangwar, M., Gopal, N., Rao, C.V. \& Goel, R.K., In-vitro antibacterial activity on human pathogens and total phenolic, flavonoid contents of Murraya paniculata Leaves, Asian Pacific Journal of Tropical Biomedicine, S1660-S1663 (2012).

5. Khameneh, B., Iranshahy,M., Soheili, \& Bazzaz B. S.F., Review on plant antimicrobials: a mechanistic viewpoint. Antimicrob Resist Infect Contro/8, 118 (2019).

6. WHO traditional medicine strategy: 2014-2023. https://www.who.int/publications/i/item/9789241506096

7. Singh, N., Kaur,N. \& Arora, R., Isolation and Charecterisation of Murayya paniculata ethanol seed extract for their Antioxidant component, International Journal of Pharmacy, 5(9), (2014).

8. Ukpo, G.E., Owolabi, M.A., Imaga,N.O., Oribayo, O.O. \& Ejiroghene,A.J., Effect of Carica papaya (Linn) aqueous leaf extract on pharmacokinetic profile of ciprofloxacin in rabbits. Trop J Pharm Res16(1), 127-134 (2017).

9. Clinton, C., Plant tannins: a novel approach to the treatment of ulcerative colitis. Nat Med J1,13 (2009).

10. Cushnie, Tim \& Cushnie, Benjamart \& Lamb, Andrew, Alkaloids: An overview of their antibacterial, antibiotic-enhancing and antivirulence activities. International Journal of Antimicrobial Agents. 10.1016/j.ijantimicag.2014.06.001 (2014).

11. Udoh,P., Essien,I. \& Udoh, F. Effect of Carica papaya (paw paw) seeds extract on the morphology of pituitary-gonadal axis of male Wistar rats. Phytother Res 19:1065-1068, (2005). 
12. Sofowora, A., Research on medicinal plants and traditional medicine in Africa. J Altern Complement Med2(3), 365-372, http://www.liebertonline. com/doi/abs/10.1089/acm.1996.2.365, (1996).

13. Rosakutty, P.J. \& Roslin, A.S. Isolation and characterization of an antimicrobial compound from the traditional medicinal plant Pittosporum tetraspermum Wight \& Arn. Int J Med Arom Plants,2,141-150 (2012)

14. Nagmoti, D.M., Khatri, D.K., Juvekar, P.R. \& Juvekar, A.R. Antioxidant activity free radical-scavenging potential of Pithecellobium dulce Benth seed extracts. Free Radicals Antioxid2(2), 37-43 (2012).

15. Bele,A.A. \& Khale,A. An overview on thin layer chromatography. J Pharmaceutical Sci,2(2), 256-267 (2011).

16. Brunetti, C., Ferdinando, M.D., Fini,A., Pollastri,S. \& Tattini, M. Flavonoids as antioxidants and developmental regulators: relative significance in plants and humans. Int J Mol Sc14(2), 3540-3555 (2013).

17. Chirinos, R., Rogez, H., Campos, D., Pedreschi, R. \& Larondelle, Y. Optimization of extraction conditions of antioxidant phenolic compounds from mashua (Tropaeolum tuberosum Ruiz and Pavon) tubers. Sep Purif Techno/55,217-225 (2007).

18. Sushmitha, H.S., Rajesh, V., Madappa, M.B. \& Sathyamurthy, B. A comparative study on characterization of various extracts of a medicinal plants. Eur J Pharm Med Res5(6),401-407 (2019).

19. Chen, Y.F., Yang, C.H., Chang, M.S., Ciou Y.P.\& Huang, Y.C. Foam properties and detergent abilities of the saponins from Camellia oleifera. Int J Mol Sci11(11), 4417-4425 (2010).

20. Brinda, P., Sasikala, B. \& Purushothaman. K. Pharmacognostic studies on Merugan kilzhangu. BMEBR 3, 84-96 (1981).

21. Elekofehinti, 0.O. Saponins: anti-diabetic principles from medicinal plants - a review. Pathophysiology 22(2), 95-103, http://dx.doi.org/https://doi.org/10.1016/j.pathophys.2015.02.001 (2015).

22. Villano, D., Fernandez-Pachon, M.S., Moya, M.L., Troncoso, A.M. \& Garcia-Parrilla, M.C. Radical scavenging ability of polyphenolic compounds towards DPPH free radical. Talanta71, 230 (2007).

23. Ghasemzadeh, A. Flavonoids and phenolic acids: role and biochemical activity in plants and human. Journal of Med Plants Res5(31), 6697-6703 (2011).

24. Kumar, S. \& Pandey, A.K. Chemistry and biological activities of flavonoids: an overview. Hindawi Publishing Corporation The Scientific World Journal.2013, http://dx.doi.org/10.1155/2013/162750 (2013).

25. Chahar, M.K., Sharma, N., Dobhal, M.P. \& Sharma, Y.C. Flavonoids: a versatile source of anticancer drugs. Pharmacognosy Rev 5(9), (2011). http://www.phcogrev.com/text.asp?2011/5/9/1/79093

26. Couraud, S., Dell'Aniello, S., Bouganim, N. \& Azoulay, L. Cardiac glycosides and the risk of breast cancer in women with chronic heart failure and supraventricular arrhythmia. Breast Cancer Res Treat146(3),619-626 (2014).

27. Robbins, C.T.,et al. Role of tannins in defending plants against ruminants: reduction in protein availability. Ecology68, 98-107 (1987).

28. Zakia, K., Kong, H.S., Nur Hazerra, B.M.Z, Chua, H.C. \& Irshad, U.H.B. Determination of polyphenolic content, HPLC analyses and DNA cleavage activity of Malaysian Averrhoa carambola fruit extracts. J King Saud Univ Sci. (2015).

29. S.S. Papaya (Carica papaya L.) seed oil. In: Ramadan M (ed) Fruit Oils: Chemistry and Functionality. Springer, Cham. (2019).

30. Vij, T. \& Prashar. Y. A review on medicinal properties of Carica papayaAsian Pacific J Trop Dis5(1),1-6 (2015).

31. Halliwell, B., Aeschbach, R., Loliger, J. \& O.I. The characterization of antioxidants. Food Chem Toxico/33(7),601-617 (1995).

32. Cao, G., Sofic, E. \& Prior. R.L. Antioxidant capacity of tea and common vegetables. J Agricul Food Chem44(11). 3426-3431 (1996).

33. Cushnie,T. \& Lamb, A.J. Antimicrobial activity of flavonoids. Int J Antimicrobial Agents26(5), 343-356, (2005).

34. Zhang, J.Y., Li,N, Che,Y.Y., et al. Characterization of seventy polymethoxylated flavonoids (PMFs) in the leaves of Murraya paniculata by on-line highperformance liquid chromatography coupled to photodiode array detection and electrospray tandem mass spectrometry. J Pharm Biomed Anal,56(5), 950-961, (2011).

35. Xu, G.H.,Chen,J.C., Liu,D.H., Zhang, Y.H., Jiang, P. \& Ye. X.Q. Minerals, phenolic compounds, and antioxidant capacity of citrus peel extract by hot water. J Food Sci. 73(1), C11-8, (2008).

36. Yu, J., Wang, L., Walzem, R.L., Miller, E.G., Pike, L.M. \& Patil, B.S. Antioxidant activity of citrus limonoids, flavonoids, and coumarins. J Agric Food Chem, 53(6), 2009-14 (2005).

37. Río, J. A. D., Gómez, P., Baidez, A.G., Arcas, M.C., Botía, J.M. \& Ortuño, A. Changes in the Levels of Polymethoxyflavones and Flavanones as Part of the Defense Mechanism of Citrus sinensis(Cv. Valencia Late) Fruits against Phytophthora citrophthora. Agric. Food Chem.52,1913-1917 (2004).

38. Río, J.A.D., Arcas,M.C., Benavente-García, O. \& Ortuño, A. Citrus Polymethoxylated Flavones Can Confer Resistance against Phytophora citrophthora, Penicillium digitatum, and Geotrichum J. Agric. Food Chem.46, 4423-4428 (1998).

39. Piluzza, G. \& Bullitta, S. Correlations between phenolic content and antioxidant properties in twenty-four plant species of traditional ethnoveterinary use in the Mediterranean area,Pharmaceutical Biology, 49:3, 240-247 (2011).

40. Coté, J., Caillet, S., Doyon, G., Sylvain, J.F. \& Lacroix, M. Bioactive compounds in cranberries and their biological properties. Rev. Food Sci. Nutr50, 666679 (2010).

41. Benslama,A. \& Harrar, A. Free radicals scavenging activity and reducing power of two Algerian Sahara medicinal plants extracts, $J$ of Herbal Medicine,4(6), 158-161 (2016).

42. Benzie, I.F.F.\& Devaki, M. The ferric reducing/antioxidant power (FRAP) assay for non-enzymatic antioxidant capacity: concepts, procedures, limitations and applications. (ed. by Apak, R., Capanoglu, E. \& Shahidi, F. Measurement of Antioxidant Activity \& Capacity: Recent Trends and Applications) (John 
Wiley \& Sons Ltd., 2018) First published:15 December 2017. Print ISBN:9781119135357 |Online ISBN:9781119135388 |DOI:10.1002/9781119135388. https://doi.org/10.1002/9781119135388.ch5

43. Rice-Evans, C. A., Miller, N. J. \& Paganga, G. Antioxidant properties of phenolic compounds, Trends in Plant Science, 4,304-309, (1997).

44. Benzie, F. F. \& Szeto, Y.T. Total antioxidant capacity of teas by the ferric reducing/antioxidant power assay, Journal of Agricultural and Food Chemistry. 47(2), 633-636 (1999).

45. Oyedapo, 0.0., Akinpelu, B. A. \& Orefuwa, S.0. Anti-inflammatory effect of Theobroma cacao root extract. J Trop Med Plants. 5(2),161-6 (2004).

46. Hendra, R., Ahmad, S., Sukari, A., Shukor, M. Y. \& Oskoueian, E. Flavonoid analyses and antimicrobial activity of various parts of Phaleria macrocarpa (Scheff.) Boerl fruit. Int J Mol Sci.12, 3422-3431 (2011).

47. Salawu, S. O., Ogundare, A. O., Ola-Salawu, B.B. \& Akindahunsi, A. A. Antimicrobial activities of phenolic containing extracts of some tropical vegetables. Afric J Pharm Pharmacol.5(4), 486-492 (2011).

48. Adnan, S. N., Ibrahim, N. \& Yaacob, W. A. Disruption of methicillin-resistant Staphylococcus aureusprotein synthesis by tannins. Germs. 7(4),186-192 (2017).

49. Scalbert, A. Antimicrobial properties of tannins. Phytochemistry. 30, 3875-3883 (1991).

50. Lloyd, W. J.,Broadhurst, A.V, Hall, M.J.,Andrews, K.J.M., Barber, W.E., Wong-Kai-In, P. Cyclohexane Triones, Novel Membrane -Active Antibacterial Agents. Antimicrobial agents and Chemotherapy, 32 (6), 814-818 (1988).

51. Perkin, W.H. \& F.R.S, XXIX. On some new bromine derivatives of coumarin. J. Chem. Soc.23, 368-371 (1870).

52. Ryu C-K, Song AL, Lee JY, Hong JA, Yoon JH, Kim A, Synthesis and antifungal activity of benzofuran-5-ols. Bioorg. Chem. Lett. 20, 6777-6780 (2010).

53. Abdel-Wahab, B.F., Abdel-Aziz, H.A. and Ahmed, E.M. Synthesis and antimicrobial evaluation of 1-(benzofuran-2-yl)-4-nitro-3-arylbutan-1-ones and 3(benzofuran-2-yl)-4, 5-dihydro-5-aryl-1-[4-(aryl)-1, 3-thiazol-2-yl]-1 H-pyrazoles, Eur. J. Med. Chem. 44, 2632-2635 (2009).

54. Manna, K. and Agrawal, Y.K. Design, synthesis, and antitubercular evaluation of novel series of 3-benzofuran-5-aryl-1-pyrazolyl-pyridylmethanone and 3benzofuran-5-aryl-1-pyrazolylcarbonyl-4-oxo ... J. Med. Chem. 45, 3831-3839 (2010).

55. Roopashree, T. S., Dang, R., Rani, S. R. H. \& Narendra, C. Antibacterial activity of anti-psoriatic herbs: Cassia tora, Momordica charantia and Calendula officinalis. International Journal of Applied Research in Natural Products. 1(3), 20-28 (2008).

56. Audu, S. A., Mohammed, I. \& Kaita, H. A., Phytochemical screening of the leaves of Lophira lanceolata (Ochanaceae). Life Science Journal.4(4), 75-79 (2007).

57. Obasi, N. L., Egbuonu, A. C. C., Ukoha, P.O. \& Ejikeme, P.M. Comparative phytochemical and antimicrobial screening of some solvent extracts of Samanea samanAfrican journal of pure and applied chemistry. 4(9), 206-212 (2010).

58. Singleton, V. L. \& Rossi, J. A. Colorimetry of total phenolics with phosphomolybdic-phosphotungstic acid reagents. The American Journal of Enology and Viticulture. 16, 144-158 (1965).

59. Arvouet-Grand, A., Vennat, B., Pourrat, A. and Legret, P. Standardization d'uneextrait de propolis et identification des principaux constituents. Journal de Pharmacie de Belgique, 49, 462-468 (1994).

60. Quettier, D.C. et al. Phenolic compounds and antioxidant activities of buckwheat (Fagopyrum esculentum Moench) hulls and flour. Ethnopharmacol. 72, 35-42 (2000).

61. Marinova, D., Ribarova, F.\& Atanassova, M. Total phenolic and total flavonoids in Bulgarian fruits and vegetables. Journal of the University of Chemical Technology and Metallurgy. 40(3), 255-260 (2005).

62. Re, R., Pellegrini, N., Proteggente, A., Pannala, A., Yang, M. \& Rice-Evans, C. Antioxidant activity applying an improved ABTS radical cation decolorization assay. Journal of Free Radical Biology and Medicine. 26, 1231-1237 (1999).

63. Ruch, R. J., Cheng, S. J. \& Klaunig, J. E. Prevention of cytotoxicity and inhibition of intracellular communication by antioxidant catechins isolated from Chinese green tea. Carcinogenesis. 10, 1003-1008 (1989).

64. Benzie, I. F. \& Strain, J.J. The ferric reducing ability of plasma (FRAP) as measurement of antioxidant power: The Frap assay. Analytical Biochemistry. 239, 70-76 (1996).

65. Oyaizu, M. Studies on products of browning reactions: antioxidant activities of products of browning reaction prepared from glucose amine. Japanese Journal of Nutrition. 44, 307-315 (1986).

66. Gandhisan, R., Thamaraichelvan, A. \& Baburaj, K. Anti-inflammatory action of Lannea coromandelica HRBC membrane stabilization. Fitotherapia. 62, 8283 (1991).

67. Chamlagai, D. \& Singh, B. Study of in vitro anti-inflammatory activity of ethnomedicinal plants of sikkim Viscum articulatum and Acorus calamus. Asian journal of pharmaceutical and clinical research. 9, 119-122 (2016).

68. Threlfall, E.J., Fisher, I. S. T., Ward, L., Tschape, H. \& Gerner-Smidt, P. Harmonization of antibiotic susceptibility testing for salmonella: results of a study by 18 national reference laboratories within the european union-funded enter-net group. Microb. drug resist. 5, 195-199 (1999).

69. Prescott J.F., Baggot J.D., Walker R.D., Antimicrobial susceptibility testing and interpretation of results. In: Antimicrobial Therapy in Veterinary Medicine (ed. Ames, I.A.) 12-26 (lowa State University Press, 2000).

70. George W Jr Latimer of referencing in official methods of analysis of AOAC International, 20th edition, (AOAC International, 2016).

\section{Tables}

Table 1. Quantification of total Phenolic and Flavonoid contents in M. paniculata leaves extracts. 


\begin{tabular}{|lll|}
\hline $\begin{array}{l}\text { M. paniculata } \\
\text { Extracts }\end{array}$ & $\begin{array}{l}\mathrm{TPC}^{1} \\
\text { (mg Gallic acid Equivalent/g } \\
\text { dry material) }\end{array}$ & $\begin{array}{l}\mathrm{TFC}^{2} \\
\text { (mg Quercetine Equivalent/g } \\
\text { dry material) }\end{array}$ \\
\hline MPH & $01.01 \pm 0.01$ & $0.614 \pm 0.08$ \\
\hline MPA & $12.02 \pm 0.59$ & $1.004 \pm 0.02$ \\
\hline MPC & $01.68 \pm 0.11$ & $0.609 \pm 0.03$ \\
\hline MPM & $14.54 \pm 0.63$ & $1.987 \pm 0.04$ \\
\hline MPW & $03.20 \pm 0.12$ & $1.619 \pm 0.04$ \\
\hline
\end{tabular}

${ }^{1}$ Total phenolic content and ${ }^{2}$ Total flavonoids content expressed in Mean \pm SE

Table 2. Free radical scavenging ability of $M$. paniculata extracts from ABTS and $\mathrm{H}_{2} \mathrm{O}_{2}$ scavenging assays, FRAP values represents as equivalent of Fe2+ /gram sample.

\begin{tabular}{|llllll|}
\hline Sample & ABTS & & H2O2 & & FRAP value \\
\cline { 2 - 5 } & $\begin{array}{l}\text { IC50 value }(\mu \mathrm{g} / \mathrm{ml}) \\
\text { Mean } \pm \text { SE }\end{array}$ & R2 & $\begin{array}{l}\text { IC50 value }(\mu \mathrm{g} / \mathrm{ml}) \\
\text { Mean } \pm \text { SE }\end{array}$ & R2 & \\
\hline MPH & $854.00 \pm 1.59^{*}$ & 0.995 & $509.84 \pm 3.03^{*}$ & 0.982 & $0.011 \pm 0.001$ \\
\hline MPA & $555.18 \pm 1.68^{*}$ & 0.989 & $812.65 \pm 22.29^{*}$ & 0.965 & $0.051 \pm 0.003$ \\
\hline MPM & $684.39 \pm 3.68^{*}$ & 0.972 & $639.26 \pm 11.84^{*}$ & 0.986 & $0.085 \pm 0.002$ \\
\hline MPC & $786.29 \pm 3.16^{*}$ & 0.986 & $594.47 \pm 0.92^{*}$ & 0.982 & $0.020 \pm 0.000$ \\
\hline MPW & $814.82 \pm 6.27^{*}$ & 0.992 & $732.80 \pm 7.9^{*}$ & 0.932 & $0.046 \pm 0.002$ \\
\hline AA & $664.90 \pm 2.81^{*}$ & 0.992 & $528.01 \pm 4.37^{*}$ & 0.983 & $0.223 \pm 0.002$ \\
\hline
\end{tabular}

$n=3, \quad *=P$ value $<0.001$ represents significance of difference from standard group

Table 3. Effect of M. paniculata extracts and Indomethacin on HRBC membrane hemolysis and protection

\begin{tabular}{|lllllllllll}
\hline Conc $^{n}$ & \% Hemolysis & & & & & \multicolumn{4}{c}{$\%$ Protection } \\
\cline { 2 - 10 }$(\mu / \mathrm{ml})$ & MPH & MPA & MPC & MPM & MPW & INDO & MPH & MPA & MPC & MPM \\
1000 & $85.80 \pm 0.95$ & $77.36 \pm 0.32$ & $92.34 \pm 0.6$ & $59.36 \pm 1.35$ & $91.9 \pm 1.27$ & $85.96 \pm 0.99$ & $14.19 \pm 0.95$ & $22.63 \pm 0.32$ & $7.65 \pm 0.60$ & $40.64 \pm 1.35$ \\
2000 & $50.73 \pm 1.37$ & $66.38 \pm 0.70$ & $86.59 \pm 0.87$ & $48.34 \pm 4.35$ & $73.7 \pm 1.98$ & $72.21 \pm 0.64$ & $49.26 \pm 1.37$ & $33.61 \pm 0.70$ & $13.40 \pm 0.87$ & $51.66 \pm 4.35$ \\
\hline 3000 & $45.53 \pm 0.58$ & $48.04 \pm 0.60$ & $81.51 \pm 1.17$ & $43.15 \pm 1.2$ & $40 \pm 2.33$ & $53.31 \pm 0.73$ & $54.46 \pm 0.58$ & $51.95 \pm 0.60$ & $18.48 \pm 1.16$ & $56.85 \pm 1.19$ \\
4000 & $40.04 \pm 0.86$ & $46.69 \pm 0.81$ & $77.03 \pm 1.25$ & $37.81 \pm 1.94$ & $32 \pm 2.69$ & $36.05 \pm 0.85$ & $59.95 \pm 0.86$ & $53.30 \pm 0.81$ & $22.96 \pm 1.25$ & $62.19 \pm 1.94$ \\
\hline 5000 & $34.85 \pm 0.18$ & $40.12 \pm 0.90$ & $73.37 \pm 1.19$ & $29.06 \pm 5.31$ & $19.5 \pm 0.76$ & $16.7 \pm 0.8$ & $65.14 \pm 0.18$ & $59.87 \pm 0.90$ & $26.63 \pm 1.19$ & $70.93 \pm 5.31$ \\
\hline
\end{tabular}

Values are Mean $\pm S D, n=3$ in each concentration. HRBC: Human red Blood Cells, INDO: Indomethacin

Table 4. Anti-microbial activity of various crude extracts of M. paniculata 


\begin{tabular}{|c|c|c|c|c|c|c|c|c|c|c|c|c|}
\hline \multirow[t]{3}{*}{ Crude extract } & \multicolumn{8}{|c|}{ Mean diameter $1(\mathrm{~mm})$ of inhibition zone of bacterial strains2 } & \multicolumn{4}{|c|}{$\begin{array}{l}\text { Mean diameter1 }(\mathrm{mm}) \text { of inhibition zone of } \\
\text { fungal strains2 }\end{array}$} \\
\hline & \multicolumn{2}{|l|}{ Ec } & \multicolumn{2}{|l|}{ Bs } & \multicolumn{2}{|l|}{$\mathrm{Pa}$} & \multicolumn{2}{|l|}{ Sa } & \multirow{2}{*}{$\begin{array}{l}\text { Ca } \\
\text { Inhibition } \\
\text { zone }\end{array}$} & \multirow{2}{*}{$\begin{array}{l}\text { Pc } \\
\text { Inhibition } \\
\text { zone }\end{array}$} & \multirow{2}{*}{$\begin{array}{l}\text { An } \\
\text { Inhibition } \\
\text { zone }\end{array}$} & \multirow{2}{*}{$\begin{array}{l}\text { Af } \\
\text { Inhibition } \\
\text { zone }\end{array}$} \\
\hline & $\begin{array}{l}\text { Inhibition } \\
\text { zone }\end{array}$ & $\begin{array}{l}\text { MIC } \\
\mu \mathrm{g} / \mathrm{ml}\end{array}$ & $\begin{array}{l}\text { Inhibition } \\
\text { zone }\end{array}$ & $\begin{array}{l}\text { MIC } \\
\mu \mathrm{g} / \mathrm{ml}\end{array}$ & $\begin{array}{l}\text { Inhibition } \\
\text { zone }\end{array}$ & $\begin{array}{l}\text { MIC } \\
\mu \mathrm{g} / \mathrm{ml}\end{array}$ & $\begin{array}{l}\text { Inhibition } \\
\text { zone }\end{array}$ & $\begin{array}{l}\text { MIC } \\
\mu \mathrm{g} / \mathrm{ml}\end{array}$ & & & & \\
\hline MPH & 3.3 & 100 & 3.6 & 50 & 4.3 & 250 & 3.6 & 1000 & 3.6 & 1000 & 3.6 & 1000 \\
\hline MPA & 3 & 500 & $\mathrm{NF}$ & NF & 3 & 500 & NF & NF & NF & NF & NF & $\mathrm{NF}$ \\
\hline MPC & 5.3 & 500 & 4 & 1000 & 3.3 & 250 & NF & NF & NF & NF & NF & NF \\
\hline MPM & 5.6 & 1000 & NF & NF & 4 & 250 & 3.3 & 500 & 3.3 & 500 & 3.3 & 500 \\
\hline MPW & $\mathrm{NF}$ & $\mathrm{NF}$ & 4 & 1000 & 3 & 25 & $\mathrm{NF}$ & $\mathrm{NF}$ & $\mathrm{NF}$ & $\mathrm{NF}$ & $\mathrm{NF}$ & $\mathrm{NF}$ \\
\hline Ciprofloxacin & 25.3 & 25 & 20.3 & 25 & 29.6 & 25 & 24.3 & 25 & - & - & - & - \\
\hline
\end{tabular}

${ }^{1} n=3$ Standard error was $<15 \%$ of mean in all cases, ${ }^{2}$ Ec: Escherichia coli, Bs: Bacillus subtilius, Pa: Pseudomonas aeruginosa, Sa: Staphylococcus aureus, Ca: Candida albicans, Pc: Penicillium chrysogenum, An: Aspergillus niger and Af: Aspergillus flavus. ${ }^{3} \mathrm{NF}$ : Not found any zone of inhibition

Table 5. Anti bacterial activity of fractions of M. paniculata hexane extract

\begin{tabular}{|c|c|c|c|c|c|c|c|c|}
\hline \multirow[t]{3}{*}{ Fractions } & \multicolumn{8}{|c|}{ Mean diameter ${ }^{1}(\mathrm{~mm})$ of inhibition zone of bacterial strains } \\
\hline & Ec & & Bs & & $\mathrm{Pa}$ & & Sa & \\
\hline & Inhibition zone & $\begin{array}{l}\text { MIC } \\
\mu \mathrm{g} / \mathrm{ml}\end{array}$ & Inhibition zone & $\begin{array}{l}\text { MIC } \\
\mu \mathrm{g} / \mathrm{ml}\end{array}$ & Inhibition zone & $\begin{array}{l}\text { MIC } \\
\mu \mathrm{g} / \mathrm{ml}\end{array}$ & Inhibition zone & $\begin{array}{l}\text { MIC } \\
\mu \mathrm{g} / \mathrm{ml}\end{array}$ \\
\hline PC1 & $\mathrm{NF}$ & $\mathrm{NF}$ & 3 & 1000 & 3 & 250 & 3 & 1000 \\
\hline PC2 & 3 & 250 & 3.3 & 25 & 9.6 & 250 & NF & NF \\
\hline PC3 & NF & NF & 2.3 & 1000 & 3 & 1000 & $\mathrm{NF}$ & NF \\
\hline PC4 & 3 & 250 & 3.3 & 250 & 6.3 & 25 & 3 & 250 \\
\hline PC11 & 2.3 & 500 & 3 & 1000 & 4.6 & 500 & 3.3 & 1000 \\
\hline PC22 & NF & $\mathrm{NF}$ & 3 & 250 & 3 & 250 & 3.6 & 250 \\
\hline Ciprofloxacin & 25.3 & 25 & 20.3 & 25 & 29.6 & 25 & 24.3 & 25 \\
\hline
\end{tabular}

Ec: Escherichia coli, Bs: Bacillus subtilis, Pa: Pseudomonas aeruginosa, Sa: Staphylococcus aureus. NF: Not found any zone of inhibition. ${ }^{1} n=3$ Standard error was $<15 \%$ of mean in all cases.

Table 6. The major components found in the PC4 fraction (Acetone : Methanol) of Hexane extract

\begin{tabular}{|c|c|c|c|c|c|c|c|}
\hline Si No & Area & Area\% & Compound Name & RT & Score (Lib) & Mol. Wt & Mol. Formula \\
\hline 1 & 16972971.39 & 3.05 & 2-Propenoic Acid, 2-Methyl-(Tetrahydro-2-Furanyl)Methyl Ester & 3.081 & 86.51 & 170.21 & $\mathrm{C}_{9} \mathrm{H}_{14} \mathrm{O}_{3}$ \\
\hline 2 & 222543567 & 40.11 & Cyclohexane & 3.169 & 92.86 & 84.16 & $\mathrm{C}_{6} \mathrm{H}_{12}$ \\
\hline 3 & 12736050.36 & 2.29 & Heptane, 2,3-dimethyl & 3.324 & 82.69 & 126.24 & $\mathrm{C}_{9} \mathrm{H}_{20}$ \\
\hline 4 & 42629434.93 & 7.68 & Hydroperoxide, 1-ethylbutyl & 5.872 & 85.51 & 118.17 & $\mathrm{C}_{6} \mathrm{H}_{14} \mathrm{O}_{2}$ \\
\hline 5 & 40284396.03 & 7.26 & Hydroperoxide, 1-ethylbutyl & 6.027 & 88.62 & 118.17 & $\mathrm{C}_{6} \mathrm{H}_{14} \mathrm{O}_{2}$ \\
\hline 6 & 38726663.88 & 6.98 & 9,12,15-octadecatrienoic acid, methyl ester, (Z,Z,Z)- & 23.142 & 87.82 & 292.5 & $\mathrm{C}_{19} \mathrm{H}_{32} \mathrm{O}_{2}$ \\
\hline 7 & 75941448.13 & 13.68 & 3-(6-Methoxy-3-methyl-2- benzofuranyl) cyclohexanone & 25.491 & 87.97 & 280.53 & $\mathrm{C}_{20} \mathrm{H}_{40}$ \\
\hline 8 & 52269994 & 9.42 & 4,4'-ethylenebis(2,6-di-tert-butylphenol) & 25.908 & 59.3 & 438.7 & $\mathrm{C}_{30} \mathrm{H}_{46} \mathrm{O}_{2}$ \\
\hline 9 & 24304527.71 & 4.38 & Phenol, 2,4-bis(1,1-dimethylpropyl)- & 26.097 & 62.69 & 234.37 & $\mathrm{C}_{16} \mathrm{H}_{26} \mathrm{O}$ \\
\hline 10 & 28369126.04 & 5.11 & 2H-1-Benzopyran-2-one, 6-(3-hydroxy-3-methylbutyl)-7-methoxy- & 26.206 & 56.79 & 260.28 & $\mathrm{C}_{15} \mathrm{H}_{16} \mathrm{O}_{4}$ \\
\hline
\end{tabular}




\section{Supplementary Materials}

Figure S1: ABTS radical scavenging activity of different concentrations of $M$. paniculata leaf extracts.

Figure $\mathrm{S} 2: \mathrm{H}_{2} \mathrm{O}_{2}$ radical scavenging activity of different concentrations of $M$. paniculata leaf extracts

Figure S3. MS spectrum of major components identified through GC-MSMS analysis.

Table S1: Phytoconstituents screening of M. paniculata leaf extracts

Table S2: Pearson's correlation coefficient (r) of dose dependent correlation between concentrations versus various extract with inhibition of hemolysis.

Table S3: Gradient solvent system used in the column-chromatography for the isolation of bioactive molecules from Hexane extract of $M$. paniculata

\section{Figures}

\section{Total antioxidant reducing capacity}

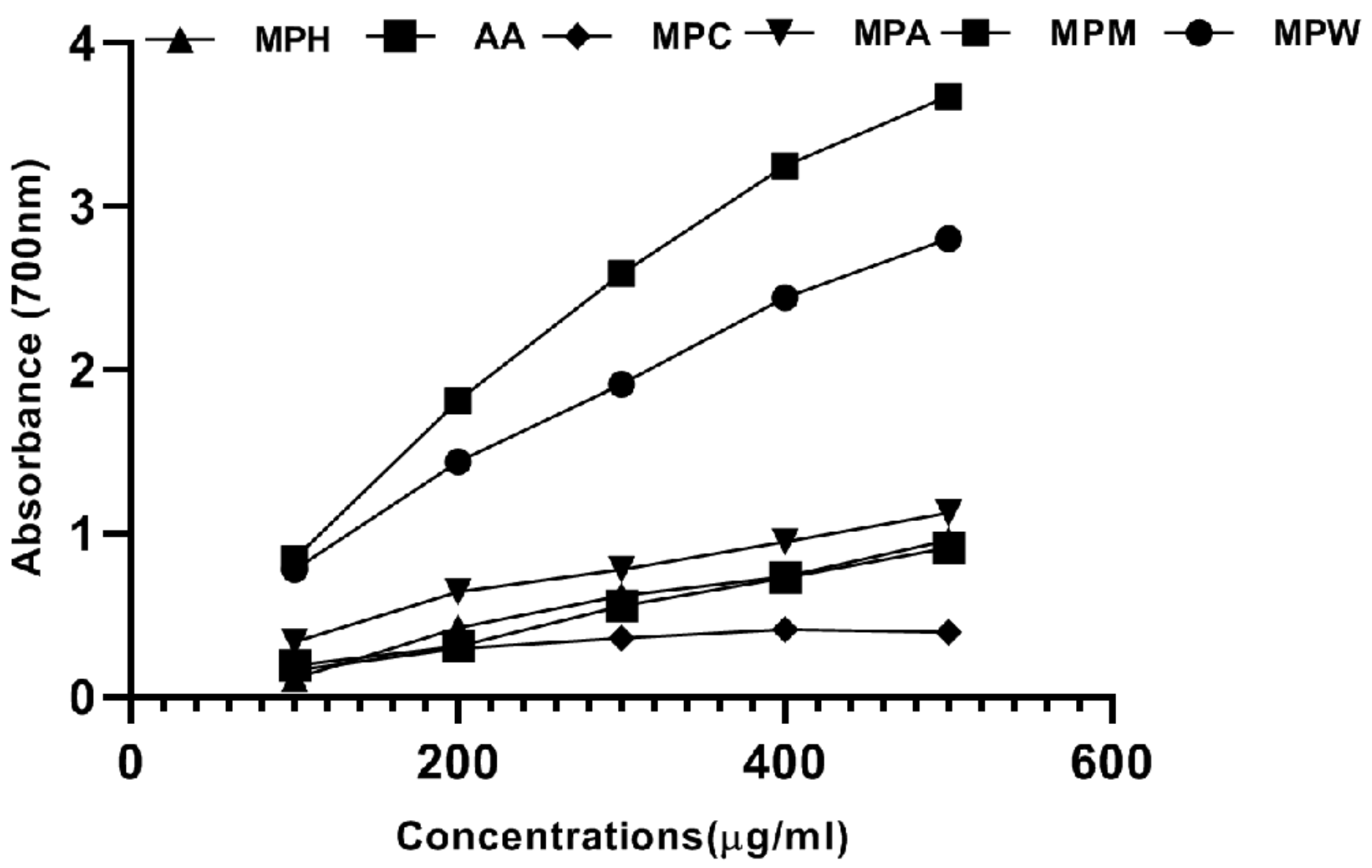

Figure 1

Total antioxidant reducing capacity of different concentrations of M. paniculata leaf extracts by reducing power assay. MPH: M. paniculata Hexane, MPA: M. paniculata Acetone, MPM: M. paniculata Methanol, MPC: M. paniculata chloroform, MPW: M. paniculata water and AA: Ascorbic acid. 


\begin{tabular}{|c|c|c|c|c|}
\hline Crude Extracts & B. subtilis & P. aureginosa & S. aureus & E. coli \\
\hline Hexane & & & & \\
\hline Acetone & & & & \\
\hline Chloroform & & & & \\
\hline Methanol & & & & \\
\hline Water & & & & \\
\hline Stand ard & & & & \\
\hline
\end{tabular}

Figure 2

Antibacterial activity of different leaf extracts of M. paniculata against B. subtilis, P. aureginosa, S. aureus and E. coli. The drug Ciprofloxacin was used as positive controls.

\begin{tabular}{|c|c|c|c|c|}
\hline $\begin{array}{c}\text { Hexane extract } \\
\text { fractions }\end{array}$ & B. subtilis & P. aureginosa & S. aureus & E. coli \\
\hline $\mathrm{PCl}$ & & & & \\
\hline $\mathrm{PC} 2$ & & & & \\
\hline PC3 & & & & \\
\hline $\mathrm{PC4}$ & & & 2 & 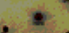 \\
\hline PC11 & & 2 & & \\
\hline $\mathrm{PC22}$ & & & & \\
\hline STD & & & & \\
\hline
\end{tabular}

Figure 3 
Antibacterial activity of hexane fractions of M. paniculata leaves against B. subtilis, P.aureginosa, S. aureus and E. coli. PC1, PC2, PC3, PC4, PC11, PC22 represents different collected fractions and the drug Ciprofloxacin were used as standard.

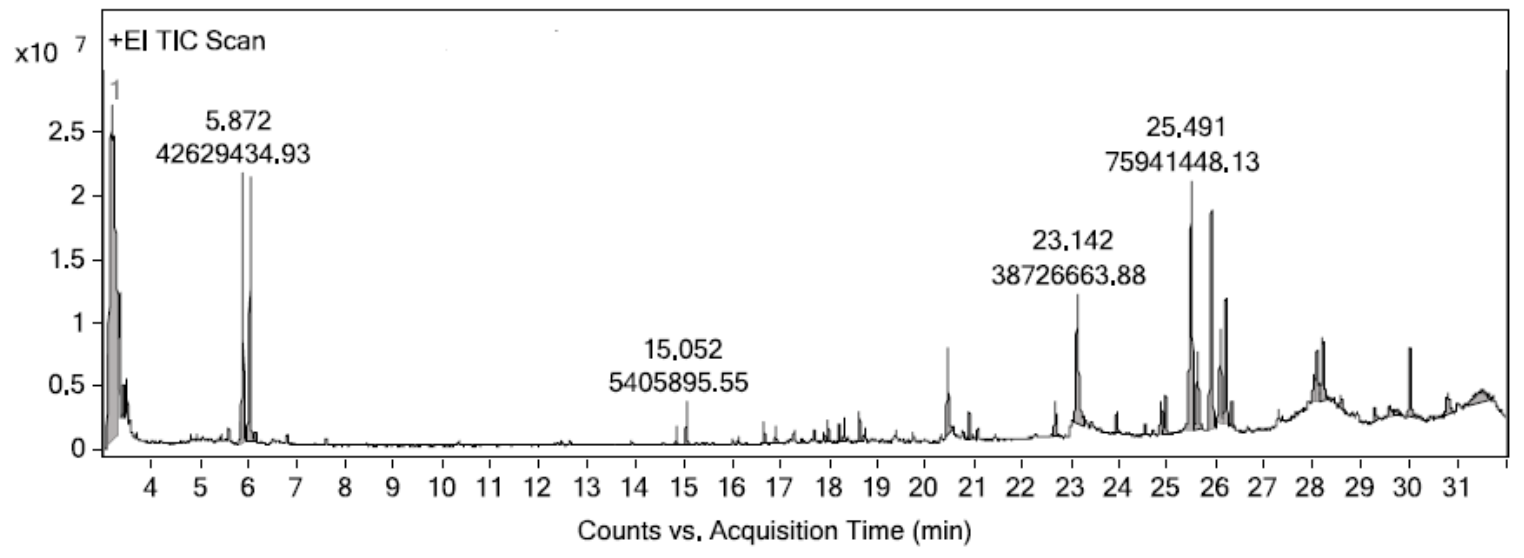

Figure 4

GC-MSMS chromatogram of PC4 fraction (Acetone: methanol) of M.paniculata Hexane extract. The peaks represent the active compounds present in the PC4 fraction.

\section{Supplementary Files}

This is a list of supplementary files associated with this preprint. Click to download.

- SupplementarySR.docx 